\title{
THE EFFECT OF COMPETENCY, MOTIVATION, AND ORGANIZATIONAL CULTURE ON THE EMPLOYEE PERFORMANCE AT THE JAYAKARTA HOTEL, BANDUNG, INDONESIA
}

\author{
Suryana H. Achmad. \\ Telkom University \\ suryana@tass.telkomuniversity.ac.id
}

\begin{abstract}
Human resources in a company is an asset that can realize the achievement of the company's mission to obtain benefits. The Jayakarta Bandung Hotel has $90 \%$ of employees who are competent and certified, but there are still complaints about the services provided. Therefore, this study was done to determine the influence of competence on performance, motivation on performance, and organizational culture on performance; and the influence of the competence, motivation, and work culture on the employee performance. This study used a quantitative research method approach with descriptive statistics, the data collection tool of questionnaires. The population was all employees of The Jayakarta Bandung Hotel with a purposive sample of 66 employees. The results showed that: employees' competence tended to be at a sufficient value (a significant effect on the performance); employees' motivation tended to be at a good value (a significant effect on the performance); and work culture tendency tended to be at a sufficient value to affect the performance. In conclusion, statistical hypotheses were accepted, indicating direct influence of X1 on $Y$ was $9.61 \%$. The value of indirect effect of X1 through X2 on $Y$ was $9.85 \%$, and that of X1 through X3 on $Y$ was $5.39 \%$. The total effect of $X 1$ was $24.80 \%$.
\end{abstract}

Keywords: HR, Competency, Motivation, Organizational Culture, Employee Performance, Bandung

\section{Introduction}

One of the components of tourism product is the hospitality industry, which is the principal means in the tourism industry. Hospitality business consists of hotel star and non-star hotels, and also cottage camps. Human resources have become the most valuable capital base of companies. Without employees, companies will not be able to generate profit to sustain their operations. Human resource management deals with wisdoms that should be implemented by the manager, which is commonly called the work management aspect.

Human resources (HR) has a major role in achieving company's mission because it is a company's asset that is subject to the achievement of predetermined goals. To achieve the required performance, the employees should be professional. To be able to measure performance well, many scholars or experts 
argue about the standards of performance that can be used, but most are varied. Martin and Baron (in Bohlander, et al, 2001) claims that "work standards should be based on job performance, associated with the outlined requirements of a job analysis and are listed in the job description and employment perspective" (Sudarmanto 2014: 9).

There is an indication at The Jayakarta Hotel in Bandung that the performance of the employees do not achieve maximum performance according to the criteria set by the hotel. I suspect the low performance of the employee is due to the less competent employees, or in other words, employees who are already certified are not completely competent in their fields, as well as due to the low motivation of employees in carrying out the service to the guests, even the organizational culture that has not done well. Besides of all front liner employees, the number of certified employees is only 61 while the number of those who are not certified yet is 5 .

Some literature suggest that employee performance is associated with competency, motivation, and organizational culture. Therefore, this study was aimed to examine the effect of competency on employee performance, motivation on employee performance, and organizational culture on employee performance, as well as the effect of competency, motivation, and organizational culture on employee performance.

\section{Literature Review \\ Competency $(\mathrm{X} 1)$}

Margaret Dale (2003:5), defines competency as the knowledge base and employee's performance standard required in order to complete a job or hold a certain position in a company. According to Mathis and Jackson (2001 in Yuniarsih and Suwanto, 2009: 23), competency is the principal characteristic of which can be adjusted with the employee performance improvement. Competency is classified into knowledge, skills, and abilities. Spencer and Spencer (1993) claims that competency is a fundamental characteristic that can be attributed to improvement of individual or group performance, and competency consists of knowledge, skill, motive, trait and self-concept.

Competency, according to SKKNI (Indonesian National Standard of Competencies), is defined as explaining about knowledge, skills, and attitudes needed in the work of employees in industry, as a training base in determining the qualifications and assessment, for both trainers and evaluators on the implementation of the training (BNSP, 2016).

From several definitions of competency above, it can be described that competency is the employees' abilities consisting of knowledge, skills and attitudes in order to complete a job or task that become their responsibility. Therefore, every employee should have required competency as an absolute requirement to be hold by every human resource. Because competency is one of the key aspects for an employee in making a good performance, competency also serves as a guide for achieving success collectively in predetermined organizational objectives. 


\section{Motivation (X2)}

Frederick Herzberg in Sondra P. Siagian (2012:164) claims that motivation comes from two factor, i.e. intrinsic satisfaction which consists of success in achieving something, gained recognition and a sense of responsibility and extrinsic satisfaction which consists of the organization's policies, supervision by managers, interpersonal relationship and working conditions. In addition, the theory of "ERG" suggests that there are three categories of individual needs, namely the existence of relatedness and growth (Veihzal Rival Zainal, 2014: 612). Below is the description of the theory of "ERG"

a. Existence includes the defense of life including physical needs.

b. Relatedness is a need to communicate with employees, have familial relationship, and related to the friendship between supervisors and other community members.

c. Growth is a desire of employees to continuously empower themselves to be productive and creative for the company's growth.

Therefore, a person's motivation arises from within the person and from the workplace environment. Motivation arising from within a person is a high awareness of a person to perform his/her tasks well without any coercion from outside, while motivation arisin from the outside is highly characterized by the work environment. If the work environment is conducive, then the person will be working diligently and vigorously. Conversely, if the work environment is less supportive, then the person will be reluctant to work properly and responsibly.

According to Veithzal R. Zainal (2014:607), motivation is a set of attitudes and values that affect individuals in achieving specific goals that have been set. Motivation includes how employees behave in achieving their objectives and the extent to which the of the employees' behavior affects their work. In addition, motive is composed of the strength that comes from the inside of the employees to do something in movement and speech. Meanwhile, motivation is the follow-up of the motive, which is an act or movement in the forms of either speech or actions in certain manners.

\section{Organizational culture (X3)}

Organizational culture is a cognitive framework that consists of attitude, value, norm of behavior and shared expectation perceived by members of an organization (Green Berg \& Baron, 2003). Organizational culture is a way of organization life generated through alternation of generations of employees. Culture includes who we are, what we believe, what we are doing (Zwell, 2000). Organizational culture is beliefs, attitudes and values which are generally owned and aris in an organization (Furham and Gunter, 1993 in Armstrong, 2003). Organizational culture is a part of the values and beliefs that underlies/becomes the identity of a company/organization (Kreitner \& Kinicki, 2001). Organizational culture refers to a system of shared meaning held by members, which distinguishes the organization's members from other organizations (HS Beeker, 1982, in Robin, Stephen, 2003). Robin (2003) identifies that organizational culture has seven primary characteristics, which are the essence of an organizational culture, namely: innovation and risk taking, attention to details, outcome orientation, people orientation, team orientation, 
aggressiveness and stability. Several factors that affect the performance of employees

From the various definitions, in principle, organizational culture refers to values, assumptions, attitudes, and norms of behavior that have been institutionalized then manifested in appearance, attitude and action, which characterize the identity of a particular organization.

\section{Employee Performance (Y)}

Employee performance is an important element in executing jobs. There are several factors that affect the performance of employees, including quality, quantity, independence, initiative, adaptability, and work skill (Flippo, 1997).

\section{Formulation of hypotheses}

The formulation of hypothesis cannot be separated from the conceptual framework. Based on the framework, then the hypotheses are formulated as follows:

1) There is an effect of competence on the employee performance at the Jayakarta Hotel Bandung.

2) There is an effect of work motivation on the employee performance at The Jayakarta Hotel Bandung.

3) There is an effect of organizational culture on the employee performance at The Jayakarta Hotel Bandung.

4) There is an effect of competence, motivation and organizational culture on the employee performance at The Jayakarta Hotel Bandung.

\section{Figure 1: Research Variables}

\begin{tabular}{|l|l|l|}
\hline COMPETENCY (X1) & \multicolumn{1}{|l|}{ MOTIVATION (X2) } \\
(Spencer \& Spencer) \\
- Knowledge \\
- Skill
\end{tabular}




\section{Methodology}

This study is a type of survey research, done at The Jayakarta Hotel in the city of Bandung, West Java, Indonesia.

\section{Population and Sample}

This study was limited on front liner staffs, consisting of 18 front office staffs, 20 housekeeping and laundry staffs, and 28 food and beverage staffs, or 66 staffs in total. All the population served as the sample in this study (Arikunto, 2007:107).

\section{Data collection}

The data in this study were collected through interviews, literature study, observation. Interviews will be conducted to the informants consisting of HR managers and employees of the hotel. Literature study will be conducted to find secondary data related research such as hotel documents and books related theories. Finally, the observations made directly by observing the object there and analyze it.

Table 1

Alternative Answers Based on the Likert Scale

\begin{tabular}{|l|l|l|l|l|l|}
\hline $\begin{array}{l}\text { Alternative } \\
\text { Answers }\end{array}$ & $\begin{array}{l}\text { Strongly } \\
\text { Agree }\end{array}$ & Agree & Doubtful & Disagree & $\begin{array}{l}\text { Strongly } \\
\text { Disagree }\end{array}$ \\
\hline Positive & 5 & 4 & 3 & 2 & 1 \\
\hline Negative & 1 & 2 & 3 & 4 & 5 \\
\hline
\end{tabular}

Source: Sugiyono (2014)

\section{Validity Test}

To test the validity of each instrument item, this study used formula of correlation coefficient of Pearson Product Moment as follows:

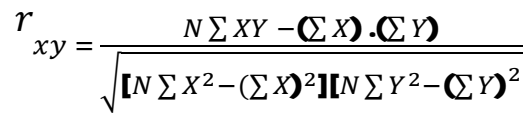

\section{Reliability Test}

To test the reliability of the instrument, this study used the formula of coefficient alpha $(\alpha)$. Below is the Cronbach cited by Somantri and Ambas Ali Muhidin (2006).

where:

$$
\begin{aligned}
& r_{11}\left[\frac{k}{k-1}\right]\left[1-\frac{\sum \sigma_{i}^{2}}{\sigma_{t}^{2}}\right. \\
& \sigma^{2}=\frac{\sum x^{2}-\frac{\left(\sum X\right)^{2}}{N}}{N}
\end{aligned}
$$

r11 : instrument reliability

$\mathrm{K}$ : number of question items

$\Sigma \sigma \mathrm{i} 2 \quad$ : number of item variants

бi2 : total variants

$\mathrm{N}$ : number of respondents 
Research Variables

Table 3

Matrix of variable operations

\begin{tabular}{|c|c|c|c|c|c|c|}
\hline \multirow[t]{2}{*}{ No } & \multirow[t]{2}{*}{ Variable } & \multirow[t]{2}{*}{ Dimension } & \multirow[t]{2}{*}{ Indicator } & \multicolumn{2}{|c|}{$\begin{array}{l}\text { Item } \\
\text { number }\end{array}$} & \multirow[t]{2}{*}{ scale } \\
\hline & & & & + & - & \\
\hline \multirow{5}{*}{1} & \multirow{5}{*}{$\begin{array}{l}\text { Competency } \\
\text { ( X1) } \\
\text { Spencer \& } \\
\text { spencer }\end{array}$} & 1. Knowledge & $\begin{array}{l}\text { 1. Knowledge of information } \\
\text { 2. The process of learning }\end{array}$ & 1,3 & 2 & Ordina \\
\hline & & 2. Skill & $\begin{array}{l}\text { 1. practical / technical } \\
\text { Expertise } \\
\text { 2. Working procedures } \\
\text { 3. Relationship }\end{array}$ & 4,6 & 5 & \\
\hline & & 3. Motive & $\begin{array}{l}\text { 1. Orientation to excel } \\
\text { 2. Certainty of work, job } \\
\text { guarantee } \\
\text { 3. The achievement of } \\
\text { organizational goals }\end{array}$ & 8,9 & 7 & \\
\hline & & 4. Trait & $\begin{array}{l}\text { 1. Self-Confidence } \\
\text { 2. Self-control } \\
\text { 3. Fortitude / durability }\end{array}$ & $\begin{array}{l}10 \\
12\end{array}$ & 11 & \\
\hline & & 5. Self-concept & $\begin{array}{l}\text { 1. customer satisfaction } \\
\text { orientation } \\
\text { 2. work outcome orientation }\end{array}$ & 13 & 14 & \\
\hline \multirow[t]{2}{*}{2} & \multirow[t]{2}{*}{$\begin{array}{l}\text { Motivation } \\
\text { (X2) } \\
\text { Frederick } \\
\text { Herzberg }\end{array}$} & $\begin{array}{l}\text { 1.Intrinsic } \\
\text { Satisfaction }\end{array}$ & $\begin{array}{l}\text { 1. Success in achieving } \\
\text { something } \\
\text { 2. Recognition obtained } \\
\text { 3. Responsibility }\end{array}$ & $\begin{array}{l}16 \\
19 \\
20\end{array}$ & $\begin{array}{l}15 \\
17 \\
18 \\
\end{array}$ & $\begin{array}{l}\text { Ordina } \\
1\end{array}$ \\
\hline & & $\begin{array}{l}\text { 2.Extrinsic } \\
\text { Dissatisfaction }\end{array}$ & $\begin{array}{l}\text { 1. Organizational policies } \\
\text { 2. Supervision by managers } \\
\text { 3. Interpersonal relationships } \\
\text { and working conditions }\end{array}$ & $\begin{array}{l}21 \\
25 \\
26 \\
27\end{array}$ & $\begin{array}{l}22 \\
23 \\
24\end{array}$ & \\
\hline \multirow[t]{4}{*}{3} & \multirow[t]{2}{*}{$\begin{array}{l}\text { Organizatio } \\
\text { nal culture } \\
\text { (X3) } \\
\text { Robin }\end{array}$} & $\begin{array}{l}\text { 1. innovation } \\
\text { and risk taking }\end{array}$ & $\begin{array}{l}\text { 1. Confidence in self- ability } \\
\text { 2. Ability to influence } \\
\text { results and decisions } \\
\text { 3. Willingness of someone to } \\
\text { try something, according to } \\
\text { the } \\
\text { others, risky }\end{array}$ & $\begin{array}{l}29 \\
30\end{array}$ & 28 & $\begin{array}{l}\text { Ordina } \\
1\end{array}$ \\
\hline & & $\begin{array}{l}\text { 2.Attention to } \\
\text { details }\end{array}$ & $\begin{array}{l}\text { 1. Accuracy, accuracy, } \\
\text { analysis of what is done } \\
\text { 2. SOP Understanding }\end{array}$ & $\begin{array}{l}31 \\
33\end{array}$ & 32 & \\
\hline & & $\begin{array}{l}\text { 3. Outcome } \\
\text { orientation }\end{array}$ & $\begin{array}{l}\text { 1. Focus on results, not } \\
\text { techniques and processes to } \\
\text { achieve outcomes. }\end{array}$ & 34 & & \\
\hline & & $\begin{array}{l}4 . \quad \text { team } \\
\text { orientation }\end{array}$ & $\begin{array}{l}\text { 1. work activities organized in } \\
\text { teams }\end{array}$ & 36 & 35 & \\
\hline
\end{tabular}




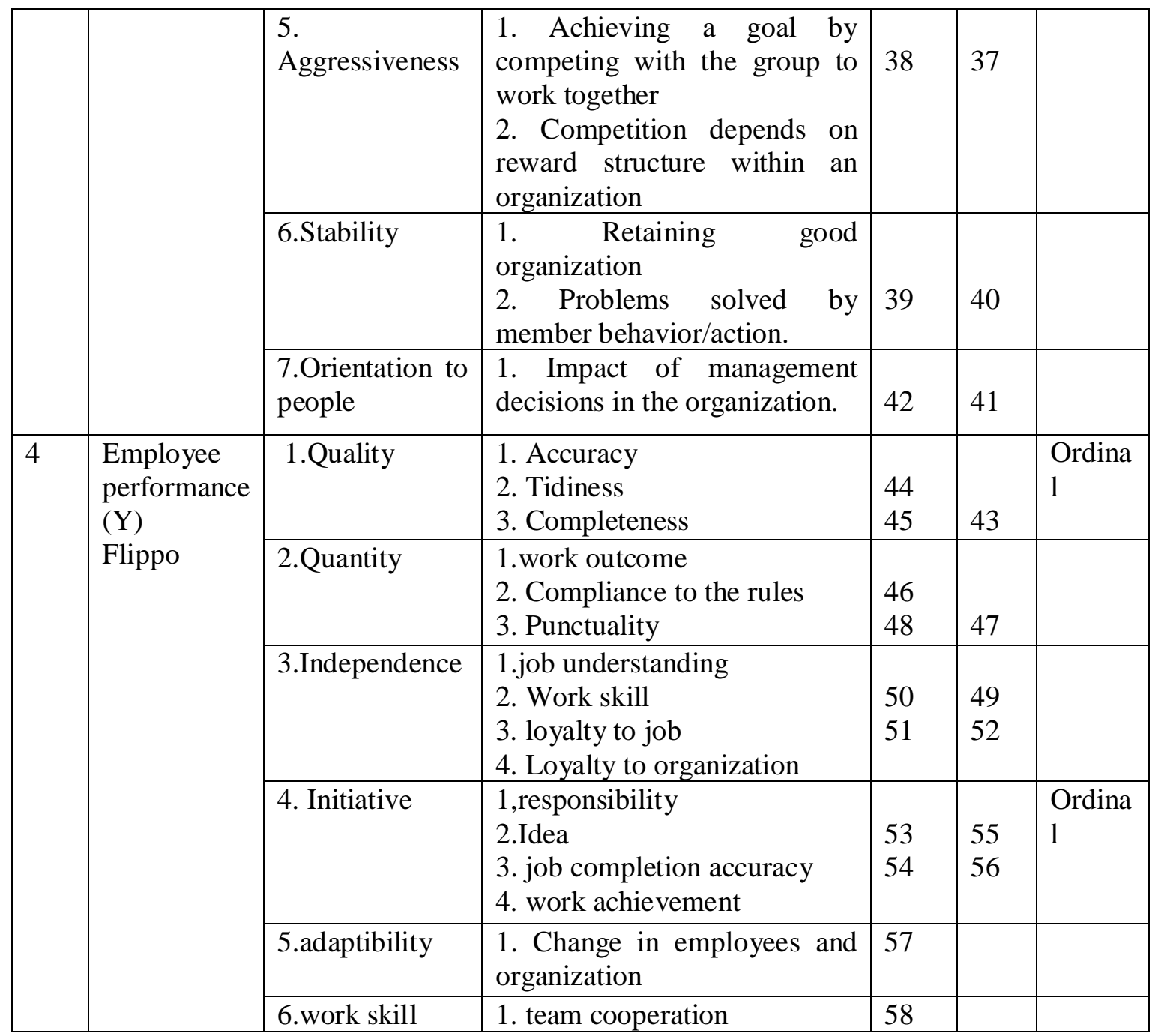

Source: Processed Data, 2016

\section{Data Processing Procedure}

Figure 2. The Used Diagram Line

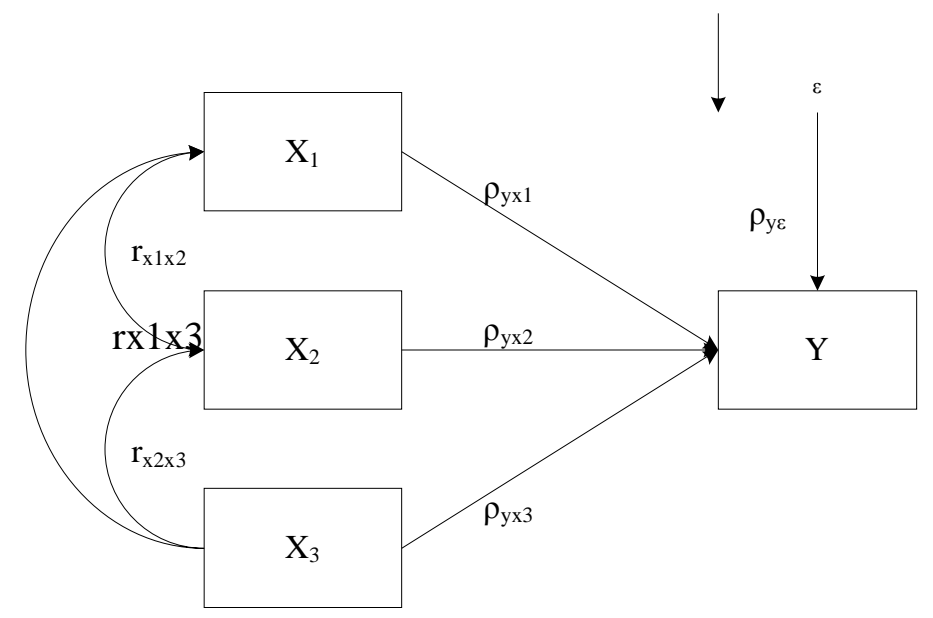


The formed structure equation is:

$\mathrm{Y}=\rho_{\mathrm{YX}_{1}} \mathrm{X}_{1}+\rho_{\mathrm{YX}_{2}} \mathrm{X}_{2}+\rho_{\mathrm{YX}_{3}} \mathrm{X}_{3}+\varepsilon$

where:

$\mathrm{X} 1$ = Competency

$\mathrm{X} 2=$ Work Motivation

X3 = Organizational Structure

$\mathrm{Y}=$ Employee Performance

\section{Results and Discussion}

\section{Effect of Competency on Employee Performance}

Competency is a requirement that must be met by every employee who works in the hospitality industry, because employees who already have a certificate of competency will know how to execute a job well as guided by three criteria a person is said to be competent, i.e. skill, knowledge and attitude. In term of competency, the analysis shows that, at The Jayakarta Hotel Bandung, Front Liner staffs are at a sufficient/moderate level. The Human Resources Manager (HRD) said that to improve the competency of his employees, every 3 months, the hotel always conducts training for employees by inviting speakers from outside).

The Jayakarta Hotel Bandung also provides the opportunity for employees to undertake training outside in accordance with their departments like taking competency test conducted by professional certification institution (LSP), or update and follow changes in terms of technologies (e.g. from fax to email). In addition, the hotel also cooperates with online travel agents in the booking system like traveloka and booking.com, to make guests easy to make reservation. The work done to improve the competency of employees is by upgrading equipment according to standards, e.g. tools generally used in the Housekeeping department.

\section{Effect of Motivation on Employee Performance}

Motivation is the basic capital that should be owned by every employee to do a job, because employees who have high motivation may have a nearly perfect performance. This happens because an employee performing a job comes from himself as a self-encouragement, who has a commitment that he/she loves and lives the job so he/she will work sincerely. This will have an impact on the motivation of the work done, i.e. becoming energetic, fast, and competitive. The data analysis shows that employee motivation at The Jayakarta Hotel Bandung is at a sufficient/moderate level from the dimensions of employee satisfaction. The HR Manager claims that, to increase employee motivation, the hotels improves the welfare of employees outside of regular income such as salaries and wages, creates an organization called "BABE", collecting and selling damaged hotel goods/tools and the money is distributed to all employees.

Another program to increase employee motivation is by facilitated the employee hobbies, e.g. sports, arts, nature lovers, all are funded by the hotel. This is in done to eliminate the saturation during work. In addition, the hotels also holds an election to select the best best staff with a prize of money (half of the salary), motivates employees by way of studying religion like reciting the Holy Qur'an one hour after the Asr prayers. The employees also earn additional incomes like from service money given by guests, holiday allowance, health 
benefits and, the retirement age of 50 years old with a large severance pay. The programs done by the management quite motivate its employees and have a major impact on employee performance.

\section{Effect of organizational culture on Employee Performance}

Organizational culture is a requirement that must be owned by leaders because leadership without using cultural principle would generate an unfavorable condition of employment, e.g assuming that the employee are only the company objects to work and be paid without viewing the nature of human hacing strenghs. Thus, a harmonious work atmosphere should be present in a company. In other words, the company will go forward if the employees are a very valuable asset for the continuation of the company.

The data analysis shows that organization culture is at medium level. This is strengthened by interview result: top leaders, in carrying out daily work, always go around (supervise) to each existing outlets at the hotel, often chat with employees who are at the bottom, for example gardener, office boy, security and so forth from the lowest staffs to the highest staffs. This has two effects, namely the positive impact: closeness to employees and the leaders can clearly know the employees' complaints thus can be accommodated by the manager and resolved quickly. Another impact is that employees feel valued and appreciated because they rarely get this kind of treatment by the top management.

\section{Effect of Competency, Motivation and Organizational Culture on Employee Performance}

The element of service is an important thing to do by a hotel employee for every guest who comes expects more services during their stay at hotel. Things to consider in providing the service is the staff performance, whether they meet the performance standards of service, perform fast, precisely and well and whether they always help the needs of guests during their stay. This is supported by the results of data analysis that performance of employees at The Jayakarta Hotel Bandung is at good level.

The data analysis shows significant results that there is a correlation between the competency, motivation and organizational culture on employee performance at the Jayakarta Hotel Bandung. Interviews with HR managers show that the simultaneous effect is seen from the achievement of corporate objectives, i.e. profit. HRD told that the Jayakarta Hotel in January 2016 experienced, for the first time, over budget amounting to five hundred million rupiah the year. Results that employees have high motivation are supported by the fact that $95 \%$ employees have been certified, as well as the comfortable organizational culture so there is no employees who resign or move to another hotel. Almost 50\% of employees the Jayakarta Hotel Bandung have been working over 15 years.

\section{Conclusions}

a. Competency has a significant effect on the performance of employees at The Jayakarta Hotel Bandung, but it has not been maximum, proven by sufficient/moderate level.

b. Work motivation has a significant effect on the employee performance at The Jayakarta Hotel Bandung, or in a sufficient/moderate level. 
c. Organizational culture has a significant effect on the employee performance at The Jayakarta Hotel Bandung, or in a sufficient/moderate level.

d. Simultaneously, competency, motivation, and organizational culture has a significant effect on the employee performance at The Jayakarta Hotel Bandung,

\section{Recommendations}

a. Employees' competency of at The Jayakarta Hotel should still be improved through various training in relation with competency standards.

b. Employees' motivation should be improved through various efforts of career development by inviting motivators.

c. Organizational culture needs to be preserved so that the atmosphere of the work environment will be better and grow so that the achievement of a work culture expected by the company.

d. Competency, motivation and organizational culture is a unity that cannot be separated from one another within an organization, because the weakness of the three aspects will inhibit the employees' performance.

\section{REFERENCES}

Abdullah, Ma'ruf, (2014). Manajemen dan Evaluasi Kinerja Karyawan, Aswaja Pressindo Yogyakarta.

Bagus I,Gusti,Metodalogi Penelitan Pariwisata \& Perhotelan,2012,CV. Andi Offset, Yogyakarta

Flippo, B. Edwin. (1997). Personal Manajemen Seven Edition. Mc Graw Hill Inc.New York

Fahmi Irham. (2014). Manajemen Teori,Kasus,dan Solusi, Alfabeta,Bandung.

Moeheriono. (2014). Pengukuran Kinerja Berbasis Kompetensi, PT. Rajagraindo Persada, Jakarta. Pustaka Yogyakarta.

Ridwan, Achmad Engkos Kuncoro (2013). Path Analysis, Analisa Jalur,Alphabeta, Bandung

Rival, Veithzal Zainal, Manajemen Sumber Daya Manusia Untuk Perusahaan. (2014) PT. Rajagrafindo Persada, Jakarta

Simajuntak J. Payaman. (2011). Manajemen \& Evaluasi Kinerja, Fakultas Ekonomi Universitas Indonesia, Jakarta.

Suryadi. (2013). Pengembangan Kinerja Pelayanan Publik, PT. Refika Aditama, Bandung.

Sugiono, Metodologi Penelitian Businis, 2014, Alfabeta, Bandung

Journal of Business on Hospitality and Tourism 
Sobirin Achmad. (2009). Budaya Organisasi, Pengertian,Makna dan Aplikasi Dalam Kehidupan Organisasi., Sekolah Tinggi Ilmu Manajemen YKPN, Yogyakarta.

Siagian P. Sondang. (2012). Teori Motivasi Dan Aplikasinya.. PT. Rineka Cipta, Jakarta

Sudarmanto, Kinerja dan Pengembangan Kompetensi Sumberdaya Manusia, Teori, Dimensi Pengukuran dan Implementasi dalam Organisasi, 2014, Pustaka Pelajar,Yoyakarta.

Susetyo Budi, Statistika Untuk Analisis Data Penelitian, 2014, PT. Refika Aditama, Bandung

Sulistiyono, Agus. (2006). Manajemen Penyeleggaraan Hotel,Alfabeta, Bandung

Spencer, Lyle. M .Jr. and Spencer, M. Signe. (1993). Competence at Work Models for Superior Performance, United States of Amerika: John Wiley \& Soon Inc.

Sugiarto, Endar. (2002). Psikologi Pelayanan dalam Industri Jasa. Jakarta: Gramedia Pustaka Utama.

Undang-Undang Republik Indonesia Nomor 9 Tentang Kepariwisataan

Wibowo, Manajemen Kinerja. (2014). PT. Rajagrafindo Persada ,Jakarta

Wibowo, Budaya Organisasi. (2013). PT.Rajagrafindo Persada, Depok 